International Journal of Economics, Business and Accounting Research (IJEBAR)

Peer Reviewed - International Journal

Vol-3, Issue-3, 2019 (IJEBAR)

E-ISSN: 2614-1280 P-ISSN 2622-4771

http://jurnal.stie-aas.ac.id/index.php/IJEBAR

\title{
EFFECT OF RURAL DEVELOPMENT POLICY AND EMPOWERMENT OF ENHANCING FOOD SECURITY IN SAROLANGUN REGENCY, JAMBI PROVINCE
}

\author{
Feri Wijaya \\ Graduate student of Master Governance Program of University Satyagama \\ E-mail:wferi99@yahoo.com
}

\begin{abstract}
Food Security is one of the economies of local communities in Indonesia, rehabilitated and reconstructed by the efforts of adequate food availability for households. However, not all areas to manage the existing resources well be the center of attention, carrying out development evenly. Therefore the role of government and the community is very important in improving food security. This study aimed to analyze the influence of Rural Development Policy and Community Empowerment against Improved Food Security in Sarolangun, either partially or collectively sama.Metode research is quantitative, and Mechanical Sampling and descriptive qualitative data analysis techniques.

The results showed that there are significant rural development policy, the low influence of community empowerment and rural development policy and community empowerment together affect the improvement of food security. Indicators of the availability of clean food staples and the percentage of areas close to $5 \mathrm{~km}$ from a health facility is to support and be an attraction in this study. Recommendations of the study: (1) The collection and compilation of data and documents on local food security, (2) Strategic Plan pangandaerah resistance and (3) food security program is short, medium and long term.
\end{abstract}

KEYWORDS : Policies, Empowerment and Food Security

\section{INTRODUCTION}

According to the Indonesian Government Regulation No. 68 Year 2002 on Food Security, Food Security is the fulfillment of the conditions of food for households that reflected the availability of adequate food, a good number, and quality, safe, equitable, and affordable. Food security is of strategic importance, because it is based on the experience in many countries shows that no country can carry out development on a steady basis before being able to achieve food security in advance.

UU no. 18 of 2012 defined food security as a condition of the fulfillment of the Food for the country up to the individual, which is reflected in the availability Food considerable, both in quantity and quality, safe, diverse, nutritious, equitable, and affordable and does not conflict with religion, faith, and culture, to be able to live healthy, active, and productive in a sustainable manner. The program to improve food security geared to meet the food needs of people in the country of national food production. Food security for a country is very important, especially for countries with a population very much like Indonesia.

Speaking of the food needs of Indonesia, one of the most important commodity is rice which became the staple food of most of the population. Interestingly, it turns out rice 
consumption per capita in Indonesia is among the highest in dunia.Diperkirakan, average rice consumption per capita reached approximately $139 \mathrm{~kg}$ per year. With a population of about 238 million people, it takes at least 34 million tons of rice per year. Domestic rice production in 2010 was only about 38 million tonnes, leaving a surplus of about 4 million tonnes of rice per year. That is, in case of emergency only able to meet less than two months.

Sarolangun is one of the districts in ProvinceJambiwhich belong to the 100 Prone Areas District Food According to the Food Security Council and Wolrd Food Program Indonesia2018. Since the formation Sarolangun in 1999, along with the already existing agricultural agencies that run the food security program. Until the year 2008, established the Food Security Office Sarolangun which has the tasks of government affairs in the field of food security, through technical policies and guidance of the implementation of activities to support food security, institutional business community in the resilience of food and the provision of agricultural extension in the broad sense as well as other duties given by the regents in accordance with the applicable legislation.

In accordance to Law No. 6 of 2014 on the village, article 1, paragraph (8) Rural Development is an effort to improve the quality of life and life to the welfare of the villagers. Furthermore, in article 1, paragraph (12) mentioned that the Village Community Empowerment is an effort to develop independence and public welfare by improving the knowledge, attitudes, skills, behavior, ability, awareness, and utilize resources through the establishment of policies, programs, activities, and mentoring appropriate the essence of the problem and the priority needs of the villagers.

The purpose of rural development, according to Law No. 6 of 2014 on the village of article 78 paragraph (1) is to improve the welfare of rural communities and the quality of human life and reduce poverty through the fulfillment of basic needs, the development of rural infrastructure, build local economic potential, as well as the utilization of natural resources and environmentally sustainable manner. To that end, the Act uses two (2) approaches, namely "Village build" and "build a village" which is integrated in the planning of Rural Development. As a consequence, the village planning development in accordance with its authority with reference to the development planning Regency / City. Document Rural Development plan is the only one planning document in the village and as the basis for preparation of the Budget of the Village.

The program to improve food security geared to meet the food needs of people in the country ofnational food production. Food security for a country is very important, especially for countries with a population very much like Indonesia. Speaking of the food needs of Indonesia, one of the most important commodity is rice which became the staple food of most of the population. Interestingly, it turns out rice consumption per capita in Indonesia is among the highest in dunia.Diperkirakan, average rice consumption per capita reached approximately 139 $\mathrm{kg}$ per year. With a population of about 238 million people, it takes at least 34 million tons of rice per year. Domestic rice production in 2010 was only about 38 million tonnes, leaving a surplus of about 4 million tonnes of rice per year. That is, in case of emergency only able to meet less than two months. 
On the basis of the research in Sarolangun with the title:"Rural Development Policy and Community Empowerment Against Increasing Food Security in Sarolangun Jambi", where the purpose of the study: (1) to analyze the influence of Rural Development Policy on Improving Food Security in Sarolangun. (2) to analyze the influence of Community Empowerment towards increased food security in Sarolangun, and (3) to analyze the influence of rural development policy and community empowerment together to increase food security in Sarolangun.

The benefits of this research are expected to provide input for the best for the community Sarolangun, especially in the priority areas of food insecurity in an effort to improve household food security become a source of increased revenue, and to provide input to the Government and Local Government in formulating policies that involve stakeholders to improve the resilience food area.

\section{RESEARCH METHODS}

To explore the research problem formulation used quantitative methods. The data collection method in this study using observation, interviews, documents, questionnaires, and literature studies. Samples were selected by simple random sampling, whereas the members of a population sample was randomly without regard to strata that exist in this population (Sugiyono;2010).

Informants as a key person in this research are three, namely the Head of Food Security Office, farmer groups and communities. This study was conducted at the location Sarolangun Jambi province with a focus on two districts include: District and Sub-district Sarolangun Lemonade. Time Frame Research on Date1 September to 1 October 2018.

\section{RESULTS AND ANALYSIS}

\section{Rural Development Policy Toward Improved Food Security in Sarolangun}

Of the acquisition value multiple linear regression model equation is known that the Rural Development Policy shows the regression coefficient is negative, it indicates the direction of negative or no relationship in the direction of rural development policy with increased food security. This means that if it is not related to the development of economic sectors increased food security will be lower, and vice versa if it made the development of economic sectors related to the improvement of food security will increase. Statement by the highest validity value is an indicator Relevant Government Elements (0.571), an indicator of competitive products $(0,459)$, and indicators of the mastery of science and technology $(0.440)$.

This is in line with the results of research in the Purwaningsih Yunastiti Journal of Development Economics (Vol. 9, No. 1, June 2008) entitled Food Security: Situation, Problems, Policy and Community Empowerment revealed that food security policy is not only to create food security with economic development with rural and agriculture is the foundation, but also the adequacy of food for the poor. In order to create community food reserves, important for improved rice barns.

Featured commodities (base) needs to be developed optimally because it has a comparative advantage that can improve comparative perekonomian.Keunggulan owned by a 
commodity can encourage the creation of competitive advantage (competitive advantage) against similar commodities in a wilayah.Keunggulan-excellence provides benefits to commodity in winning market competition. The wider the market share and ahead of the competition or have the power of the high competitiveness of products on the market allow such products is also high profit from the sales process (Tarin, 2005).

Sarolangun have a medium-term development vision for the period 2016-2021, namely "Sarolangun More Advanced and Prosperity". So as to realize the vision necessary to manage potential of the region. This can be done by identifying the leading commodity every district in Sarolangun and analyze the competitiveness of the territory. So that the process of regional economic development based on a view that there is potential in the area.

In connection with the policy of rural development in enhancing food security in Sarolangun, District Government through a decree in order to strengthen cross-sectoral coordination in implementing the Development of Food Security, the Government issued a decree Sarolangun No. 14 of 2012 as an amendment of the Decree Regent Tanjung Jabung Timur No. 200 Years 2008 on Food Security Council (FSC). Regent designated as Chairman, Vice Chairman and Assistant Secretary for Economic and Development as Chief Executive and Head of Food Security Office as Secretary of the Food Security Council.

Further fundamental change in Regulation Sarolangun No. 14 of 2012 is the number of membership of the DKP from 22 to 24 members, consisting of the heads of institution, Head of Division, Head of Section, and two Government agencies non Ministry with the task of "Formulating policy Food Security District" which includes activities in the provision of Food, Food Distribution, Food Reserves, Diversification of Food, Prevention and control of Food and Nutrition issues and to implement Food Security Evaluation Strengthening control at both district level, district and sub-district, village/villages.

\section{Community Empowerment Against Food Security Improvement in Sarolangun}

SPSS test results stating that there is no influence of empowerment to the improvement of food security in the district Sarolangun. The acquisition value of multiple linear regression model equation is known that the empowerment of the community showed regression coefficient is negative, this is due to new establishment Sarolangun Food Security Office so that the program and its function has not been understood and known by the public. Therefore, people can not understand what is meant by empowerment and food security. Then the Food Security Office should pay attention to community development programs and food security in accordance with the needs of area. It can be interpreted that if the increasing empowerment of communities then increased food security will be increased,

Statement by value The highest validity indicator Creating a desire to help others (0.924), indicator manners $(0,813)$, and indicators of potential and creativity Promotion of local products (.810). This means that these indicators are the dominant influence on Improving Food Security (Y). While the value of the lowest Validity is a statement of the four indicators Business / industry Households with the validity of (0.127). This illustrates that with increasing indicators creates a desire to help others supported by indicators and indicators of good manners and 
kretivitas potential sale of local products will be able to increase food security and food products derived Sarolangun in Jambi province.

This is reinforced by Act No. 6 of 2014 on the village together with the government, advancing with the appropriate vision and mission of the Local Government especially in improving food security in Sarolangun. As for the connection with community development, local government has been supporting Sarolangun through ADD, PDRD and DD in the respective villages in each district. The output is a document detailing the activities report (DRK), in the allocation has been budgeted for the Division of Development of Community and Rural Community Empowerment.

\section{Rural Development Policy and Community Empowerment Against Increasing Food Security in Sarolangun}

Rural Development Policy and Community Empowerment jointly affect $3.1 \%$ of the increase in food security in Sarolangun, the remaining $96.9 \%$ is influenced by variables not examined in this study.Based on Activity Allocation of Development of Rural Community Empowerment in Jambi Province Sarolangun 2018 comprised 18 events. As for the improvement of food security looks can get into the point (1) Development of Community Institutions, (2) Education, Training / Courses and Guidance for the village chief, the Village and the BPD and (3) Increasing the capacity of the community, especially with regard to the group of economically productive activities.

Table.1.

Food Security conditions in Sarolangun 2018

\begin{tabular}{|l|l|c|c|c|c|c|}
\hline \multirow{2}{*}{ No. } & \multirow{2}{*}{ sub-district } & \multicolumn{3}{|c|}{ Total population } & Population Prone to Food \\
\cline { 3 - 7 } & & Man & Woman & total & Total Soul & Total KK \\
\hline 1 & Batang Asai & 9471 & 9322 & 18793 & 1,950 & 488 \\
\hline 2 & Lemonade & 9197 & 8653 & 17850 & 1,580 & 395 \\
\hline 3 & Sarolangun & 28322 & 26628 & 54950 & 1,766 & 442 \\
\hline 4 & Pauh & 14164 & 13258 & 27422 & 2,964 & 741 \\
\hline 5 & opposition & 19296 & 18201 & 37497 & 2,760 & 690 \\
\hline 6 & Mandiangin & 22005 & 20151 & 42156 & 2,721 & 680 \\
\hline 7 & black water & 16603 & 15051 & 31654 & 2,978 & 745 \\
\hline 8 & Bathin VIII & 12449 & 11622 & 24071 & 2122 & 531 \\
\hline 9 & Singkut & 21869 & 20521 & 42390 & 3,599 & 900 \\
\hline 10 & Mirror Nan Gedang & 8089 & 7563 & 15652 & 1,889 & 472 \\
\hline \multicolumn{2}{|c|}{ Total } & $\mathbf{1 6 1 4 6 5}$ & $\mathbf{1 5 0} \mathbf{4 7 0}$ & $\mathbf{3 1 2} \mathbf{4 3 5}$ & $\mathbf{2 4 ~ 3 2 9}$ & $\mathbf{6 , 0 8 2}$ \\
\hline
\end{tabular}

The table above show 1 the highest food-insecure population is the District Singkut with the number of 900 households, 745 black Water District Pauh households and 741 families. While the population of the lowest food insecurity is Kecmatan Limnun namely KK 395 and KK 442 Sarolangun. This is according to research conducted by Sean Fitria Rohmawati Laily, et al 
(2014) reported production produced for the better and increasing, due pengetahauan and skills of farmers in planting also increases. Likewise realities on the ground, that the indicator Expertise (0.856) demonstrating the role of one's expertise both Officers Related Agencies that provide counseling on community development programs particularly in the field of food security is very important.

A powerful community, will be able to cultivate the crop into a variety of food. Thereforecall the World Commission on Environment and Development (WCED), 1987 which states that the attention to the major issues and challenges facing the world's agriculture. Namely, the needs of current and future food must be met, and the need for a new approach to the development of agriculture and food production are widely so that the world food surplus. But why do many people still starving (Barrichello, Rick, 2000) can be received by the changes that the food needs of current and future must be fulfilled by preparing the public, especially farmers' groups, into a group of farmers who advanced formed with facilitation program empowering the community to cultivate various food with in support of technological progress.

Thus, it can be concluded that the Rural Development Policy and Community development on food security, will be able to boost the economic development and welfare will be adequate food for people in Sarolangun.

\section{CONCLUSIONS AND RECOMMENDATIONS}

The conclusion of this study are:

1. Rural Development policies affect the Improvement of Food Security in Sarolangun, adapun some rural development policy issues among others: (1) The absence of regulation, Perbub about food security, (2) Lack of organizational structure department Sarolangun food security, (3) Lack of food security master plan in Sarolangun. It has been demonstrated that the results are good enough and the respondents agreed that the Rural Development Policy can affect Improved Food Security for Rural Development policy is a rule that contains actions carried out either by individuals (officials) or public or private kelompok- directed at achievement of the objectives outlined in the policy decisions continuous development.

2. Community Empowerment affect the Improvement of Food Security in Sarolangun. As for some of the problems of community empowerment among others: (1) There prevalence of community development programs, especially rural farmers groups, (2) Lack of training for farmers on food security, (3) Raising food garden. It is already mamperlihatkan that the results are good enough and the respondents agreed that the Community Empowerment can affect Improved Food Security for Community Empowerment is a concept that summarizes the development of multi-faceted. This concept represents a new development paradigm (post-developmentalism paradigm), that is people-centered, participatory, empowering, and sustainable ".

3. Rural Development Policy and Community Empowerment, jointly affect the Improvement of Food Security in Sarolangun determined by the Provincial Regulation on local food 
security, and rural food security strategic plan in order to increase food security through household food sufficiency embodied in Sarolangun.

Suggestions submitted as follows:

1. Sarolangun for Local Government, to immediately draw up a strategic plan to the rural areas of food security, food security legislation Sarolangun district are also set in the rural community empowerment mewjudkan household food sufficiency. Thus, the expected food rural development policy in Kabupten Sarolangun will further develop and improve community will be adequate food and nutrition.

2. For farmer groups and communities in the districts Sarolangun, in order to assist local governments the public welfare through food security, and nutrition to people through community empowerment programs. In order to participate, giving enter improvements to enhance food security, adequate nutrition and food in the area.

3. Local Government Sarolangun expected to synergize with farmer groups and communities to achieve food security in Sarolangun independent.

\section{REFFERENCES}

Indonesian Government Regulation No. 68 Year 2002 on Food Security

Law No. 18 of 2012 About the Food

Law No. 6 Year 2014 About the village

Sugiyono. 2010. Methods of Education. Bandung: Alfabeta

Yunastiti Purwaningsih.2008.Food Security: Situation, Problems, Policy and Community Empowerment;Journal of Development Economics (Vol. 9, No. 1, June) Tarin, 2005

Sarolangun decree No. 14 of 2012 as changes in East Tanjung Jabung Regency Decree No. 200 of 2008 on Food Security Council (DKP)

BPMPD Sarolangun.2018.Data District Food Security Conditions Sarolangun; Sarolangun

Sean Fitria Rohmawati Laily, Heru Ribawanto, and Farida Conscience.2014. Farmer Empowerment in Improving Food Security (Studies in Rural Betet, District Ngronggot, Nganjuk): Journal of Public Administration (JAP), Vol. 2, No. 1, p. 147-153

Barrichello, Rick.2000. Evaluating Government Policy for Food Security: Indonesia. Berlin: University of British Columbia. 